\title{
Effect of Acute Cold Exposure on ACTH and Zinc Concentrations in Human Plasma
}

\author{
Hideki Ohno, Takehiro Yahata, Kohki Yamashita, ${ }^{*}$ \\ and Akihiro Kuroshima \\ Department of Physiology and * Department of Obstetrics and Gynecology, \\ Asahikawa Medical College, Asahikawa, 078 Japan
}

\begin{abstract}
Summary Effects of acute cold exposure $\left(10^{\circ} \mathrm{C}\right.$ for $\left.60 \mathrm{~min}\right)$ on the concentrations of adrenocorticotropin (ACTH) and zinc in plasma were investigated in seven healthy male students. There were no significant changes in total zinc, albumin-bound zinc, and $\alpha_{2}$-macroglobulin-bound zinc concentrations throughout the experimental period. On the other hand, ACTH concentration increased markedly during cold exposure. In addition, a statistically significant inverse relationship existed between the changes in ACTH and albumin-bound zinc values during the experiment. These results suggest that acute cold exposure produces elevated plasma ACTH levels, with resulting zinc redistribution in the human body.
\end{abstract}

Key words: cold exposure, ACTH, zinc.

Zinc is without doubt one of the essential trace elements in the living organism. A number of studies have demonstrated that acute stresses including surgical trauma, burns, myocardial infarction, and a variety of acute infectious illnesses reduce plasma zinc values (BEISEL et al., 1976). Disappearance of zinc from plasma can develop within only a few hours after the initiation of a stressful insult. Our recent study in humans has shown that, despite significantly decreased erythrocyte zinc levels as well as a notable decrease in plasma volume (PV), there are no significant increases in plasma zinc concentration during acute exposure to cold (OHNO et al., 1986). It has been reported that adrenocorticotropin (ACTH) infusion into humans reduces serum zinc from 10 to $60 \mu \mathrm{g} \cdot 100 \mathrm{ml}^{-1}$ (FALCHUK, 1977) and that only $15 \mathrm{~min}$ of cold exposure leads to a marked increase in ACTH concentration in the plasma of rats (UsATEGUi et al., 1977). To our knowledge, however, reports concerning the influence of acute cold exposure on ACTH in human plasma are not available. In the present study we investigated an interrelationship between the changes in ACTH and zinc concentrations in human

Received for publication July 27, 1987 
plasma during acute exposure to cold.

The subjects were seven sedentary healthy male students whose mean $( \pm$ S.E. $)$ age, height, and weight were 21.6 years $( \pm 0.7), 174.6 \mathrm{~cm}( \pm 1.6)$, and $67.8 \mathrm{~kg}$ $( \pm 2.2)$, respectively. Informed consent was obtained from all subjects. Through late January to February, the subjects wearing only $\mathrm{T}$ shirts and shorts underwent cold exposure in the supine position at $10^{\circ} \mathrm{C}$, relative humidity of $40-50 \%$, and wind velocity less than $0.5 \mathrm{~m} \cdot \mathrm{s}^{-1}$ for $60 \mathrm{~min}$. They were allowed to rest at an ambient temperature of $25-26^{\circ} \mathrm{C}$ for $30 \mathrm{~min}$ prior to and for $15 \mathrm{~min}$ after the exposure to cold. Skin temperatures were continuously recorded with a thermistor thermometer (TER-36, Takara Kogyo, Tokyo) at five different locations (forehead, chest, forearm, thigh, and calf). Rectal temperature was recorded with a thermistor probe inserted $10 \mathrm{~cm}$ into the rectum. Mean skin and body temperatures were calculated by the method described elsewhere (Dor et al., 1979). Blood samples were collected from the antecubital vein in a zinc-free heparinized plastic syringe at 0,15 , and 60 min during cold exposure, and at 15 min after cold exposure.

Zinc concentration in plasma was assayed by use of a Shimadzu model AA 640-13 atomic absorption spectrophotometer (Tokyo) (for details see OHNO et al., 1985). The zinc distributions in plasma were determined according to the method described by GIROUX (1975). Total plasma protein concentration was measured by the method of Lowry et al. (1951). The quantitative determinations of albumin and $\alpha_{2}$-macroglobulin $\left(\alpha_{2}-\mathrm{MG}\right)$ were made by a single radial immunodiffusion technique, using Partigen plates (Behringwerke, Marburg). ACTH and cortisol concentrations were determined by commercial kits (a Green Cross ACTH radioimmunoassay kit, Tokyo and an Eiken cortisol radioimmunoassay kit, Tokyo). The plasma concentrations of norepinephrine (NE) and epinephrine (E) were assayed using a BAS model LC-304 catecholamine analyzer (Bioanalytical System, West Lafayette). Hematocrit (Hct) level was measured by a microcapillary tube technique and used to calculate changes in PV as described by VAN BEAUMONT et al. (1973). To minimize the effect of hemoconcentration on each plasma solute concentration, the Van Beaumont quotient (VBQ) (VAN BEAUMONT et al., 1973) was also determined.

Scheffe's tests were used to identify significant mean differences across time when significant $(p<0.05) F$-ratios were obtained in a one-way analysis of variance (SNEDECOR and COCHRAN, 1980). Each VBQ was evaluated for significance by the paired $t$-test. In all statistical analyses, the 0.05 level of significance was used.

Table 1 shows the temperature responses. No definite changes were observed in the rectal temperature during cold exposure, whereas both mean skin and body temperatures showed significant decreases. The mean skin temperature at $15 \mathrm{~min}$ after cold exposure remained significantly lower compared to the initial control value. Plasma NE concentration increased notably after 60 -min cold exposure and $15 \mathrm{~min}$ after cold exposure, while E concentration did not change substantially (Table 2), in agreement with the findings of previous studies (JESSEN, 1980; OHNO et al., 1986). These results on the indices of cold exposure indicate that the subjects were under possible effects of cold exposure. 
Table 1. Effects of acute exposure to cold on temperature responses.

\begin{tabular}{lcccc}
\hline \multirow{2}{*}{ Temperature } & \multirow{2}{*}{$\begin{array}{c}\text { Initial } \\
\text { control }\end{array}$} & \multicolumn{2}{c}{ During cold exposure } & \multirow{2}{*}{$\begin{array}{c}15 \mathrm{~min} \text { after } \\
\text { cold exposure }\end{array}$} \\
\cline { 3 - 4 } & & $15 \mathrm{~min}$ & $60 \mathrm{~min}$ & \\
\hline Rectal temperature $\left({ }^{\circ} \mathrm{C}\right)$ & $37.0 \pm 0.1$ & $37.1 \pm 0.1$ & $37.1 \pm 0.1$ & $36.9 \pm 0.1$ \\
Mean skin temperature $\left({ }^{\circ} \mathrm{C}\right)$ & $33.3 \pm 0.1$ & $29.3 \pm 0.3^{*}$ & $27.7 \pm 0.4^{*, * * *}$ & $31.2 \pm 0.3^{*, * * * * *}$ \\
Mean body temperature $\left({ }^{\circ} \mathrm{C}\right)$ & $35.8 \pm 0.1$ & $34.5 \pm 0.1^{*}$ & $34.0 \pm 0.1^{*}$ & $35.0 \pm 0.1^{* * *}$ \\
\hline
\end{tabular}

Values are mean \pm S.E. Significantly different from $*$ initial control, $* * 15$-min cold exposure, and $* * * 60$-min cold exposure: $p<0.05$.

Table 2. Variations in plasma concentrations of ACTH, cortisol, and catecholamines and the Van Beaumont quotient for them under acute exposure to cold.

\begin{tabular}{lcccc}
\hline & \multirow{2}{*}{$\begin{array}{c}\text { Initial } \\
\text { Parameter }\end{array}$} & \multicolumn{2}{c}{ During cold exposure } & \multirow{2}{*}{$\begin{array}{c}15 \text { min after } \\
\text { control }\end{array}$} \\
\cline { 3 - 4 } & & $15 \mathrm{~min}$ & $60 \mathrm{~min}$ & \\
\hline ACTH $\left(\mathrm{pg} \cdot \mathrm{ml}^{-1}\right)$ & $32.9 \pm 3.1$ & $52.5 \pm 6.0^{*}$ & $49.9 \pm 6.3^{*}$ & $40.4 \pm 4.5$ \\
& & $\left(50.0 \pm 15.3^{*}\right)$ & $\left(34.2 \pm 10.8^{*}\right)$ & $(23.0 \pm 11.2)$ \\
Cortisol $\left(\mu \mathrm{g} \cdot 100 \mathrm{ml}^{-1}\right)$ & $11.6 \pm 1.6$ & $11.7 \pm 2.3$ & $10.7 \pm 2.2$ & $9.11 \pm 2.1$ \\
& & $(-4.32 \pm 6.86)$ & $(-11.3 \pm 5.4)$ & $(-16.0 \pm 6.7)$ \\
Norepinephrine & $470.4 \pm 70.2$ & $695.7 \pm 83.7$ & $854.4 \pm 114.5^{*}$ & $751.0 \pm 108.6^{*}$ \\
$\left(\mathrm{pg} \cdot \mathrm{ml}^{-1}\right)$ & & $\left(44.3 \pm 13.6^{*}\right)$ & $\left(67.5 \pm 22.7^{*}\right)$ & $\left(53.3 \pm 16.8^{*}\right)$ \\
Epinephrine $\left(\mathrm{pg} \cdot \mathrm{ml}^{-1}\right)$ & $96.9 \pm 32.7$ & $105.7 \pm 24.5$ & $116.6 \pm 22.6$ & $106.9 \pm 17.1$ \\
& & $(44.5 \pm 31.0)$ & $(67.2 \pm 49.0)$ & $(68.6 \pm 49.5)$ \\
\hline
\end{tabular}

Values are mean \pm S.E. ACTH, adrenocorticotropic hormone. Van Beaumont quotient $(\%)$ (VAN BEAUMONT et al., 1973) is given in parentheses. ${ }^{*}$ Significantly higher than initial control: $p<0.05$.

Plasma ACTH concentration increased significantly during cold exposure and none of the VBQ for ACTH followed the decrease in PV during the experiment (Table 2). Therefore, the result suggested an influx of ACTH into the plasma as indicated by LUKASKI et al. (1984) after exercise in men fed a low-zinc diet. On the other hand, cortisol concentration did not change significantly at any time. However, the VBQ for cortisol appeared to decrease after 60-min cold exposure and at $15 \mathrm{~min}$ after cold exposure $(p<0.10)$.

As shown in Table 3, there were no significant changes in total zinc, albuminbound zinc, and $\alpha_{2}$-MG-bound zinc concentrations at any time. While plasma $\alpha_{2}$ MG concentration did not vary significantly during the experiment, there were significant elevations in total protein and albumin after 60-min cold exposure and $15 \mathrm{~min}$ after cold exposure. Conversely, the VBQ for total protein and albumin 
Table 3. Variations in plasma concentrations of zinc and related proteins and the Van Beaumont quotient for them under acute exposure to cold.

\begin{tabular}{|c|c|c|c|c|}
\hline \multirow{2}{*}{ Parameter } & \multirow{2}{*}{$\begin{array}{l}\text { Initial } \\
\text { control }\end{array}$} & \multicolumn{2}{|c|}{ During cold exposure } & \multirow{2}{*}{$\begin{array}{l}15 \mathrm{~min} \text { after } \\
\text { cold exposure }\end{array}$} \\
\hline & & $15 \mathrm{~min}$ & $60 \mathrm{~min}$ & \\
\hline $\begin{array}{l}\text { Total zinc } \\
\qquad\left(\mu \mathrm{g} \cdot 100 \mathrm{ml}^{-1}\right)\end{array}$ & $78.3 \pm 4.1$ & $\begin{array}{c}82.9 \pm 3.1 \\
(-1.19 \pm 2.84)\end{array}$ & $\begin{array}{c}86.8 \pm 3.0 \\
(-1.77 \pm 3.76)\end{array}$ & $\begin{array}{c}80.4 \pm 4.8 \\
(-4.83 \pm 3.04)\end{array}$ \\
\hline $\begin{array}{l}\text { Albumin-bound zinc } \\
\qquad\left(\mu \mathrm{g} \cdot 100 \mathrm{ml}^{-1}\right)\end{array}$ & $56.5 \pm 4.5$ & $\begin{array}{c}63.0 \pm 3.7 \\
(2.54 \pm 5.33)\end{array}$ & $\begin{array}{c}63.8 \pm 3.8 \\
(-0.329 \pm 7.984)\end{array}$ & $\begin{array}{c}59.6 \pm 3 . \dot{3} \\
(-0.857 \pm 6.734)\end{array}$ \\
\hline$\%$ of total zinc & $72.0 \pm 3.9$ & $76.1 \pm 3.7$ & $73.7 \pm 2.2$ & $74.9 \pm 3.9$ \\
\hline $\begin{array}{l}\alpha_{2} \text {-MG-bound zinc } \\
\left(\mu \mathrm{g} \cdot 100 \mathrm{ml}^{-1}\right)\end{array}$ & $21.8 \pm 3.0$ & $\begin{array}{c}19.9 \pm 3.1 \\
(-11.3 \pm 6.1)\end{array}$ & $\begin{array}{c}23.0 \pm 2.2 \\
(5.51 \pm 19.1)\end{array}$ & $\begin{array}{c}20.7 \pm 3.8 \\
(-6.84 \pm 18.5)\end{array}$ \\
\hline$\%$ of total zinc & $28.0 \pm 3.9$ & $23.9 \pm 3.7$ & $26.3 \pm 2.2$ & $25.1 \pm 3.9$ \\
\hline $\begin{array}{l}\text { Total protein } \\
\qquad\left(\mathrm{g} \cdot 100 \mathrm{ml}^{-1}\right)\end{array}$ & $7.10 \pm 0.13$ & $\begin{array}{c}7.50 \pm 0.12 \\
(-2.04 \pm 0.61 *)\end{array}$ & $\begin{array}{c}7.76 \pm 0.15^{*} \\
\left(-3.99 \pm 1.10^{*}\right)\end{array}$ & $\begin{array}{c}7.56 \pm 0.14^{*} \\
(0.229 \pm 2.228)\end{array}$ \\
\hline $\begin{array}{l}\text { Albumin } \\
\qquad\left(\mathrm{g} \cdot 100 \mathrm{ml}^{-1}\right)\end{array}$ & $4.40 \pm 0.07$ & $\begin{array}{c}4.64 \pm 0.09 \\
(-1.53 \pm 1.27)\end{array}$ & $\begin{array}{c}4.80 \pm 0.09^{*} \\
\left(-4.21 \pm 0.75^{*}\right)\end{array}$ & $\begin{array}{r}4.67 \pm 0.09^{*} \\
(-1.99 \pm 1.50)\end{array}$ \\
\hline $\begin{array}{l}\alpha_{2}-\mathrm{MG} \\
\quad\left(\mathrm{mg} \cdot 100 \mathrm{ml}^{-1}\right)\end{array}$ & $246.6 \pm 8.7$ & $\begin{array}{c}249.6 \pm 7.4 \\
(-5.67 \pm 3.40)\end{array}$ & $\begin{array}{c}264.7 \pm 10.2 \\
(-5.66 \pm 2.39)\end{array}$ & $\begin{array}{c}262.6 \pm 7.3 \\
(-1.09 \pm 2.52)\end{array}$ \\
\hline Hematocrit $(\%)$ & $43.3 \pm 0.3$ & $45.3 \pm 0.5 *$ & $46.6 \pm 0.5^{*}$ & $45.3 \pm 0.6^{*}$ \\
\hline$\triangle \mathrm{PV}(\%)$ & & $-7.19 \pm 1.27$ & $-12.1 \pm 1.69$ & $-7.27 \pm 1.85$ \\
\hline
\end{tabular}

Values are mean \pm S.E. $\alpha_{2}$-MG, $\alpha_{2}$-macroglobulin; $\Delta \mathrm{PV}$, plasma volume change. Van Beaumont quotient $(\%)($ VAN BEAUMONT et al., 1973) is given in parentheses. * Significantly different from initial control: $p<0.05$.

showed significant decreases during cold exposure. Hct level rose significantly throughout the experimental period, resulting in a remarkable decrease in PV. The VBQ for total zinc did not change significantly during the experimental period. From the fact that erythrocyte zinc levels reduced during the experiment $\left(1,140.2 \pm 33.0,1,109.1 \pm 27.0,1,113.1 \pm 26.1\right.$, and $1,110.8 \pm 45.6 \mu \mathrm{g} \cdot 100 \mathrm{ml}^{-1}$ of erythrocytes in the order of blood-collecting), however, the possibility might exist that there was an efflux of zinc from the plasma during cold exposure.

A statistically significant inverse relationship was observed between the changes in ACTH and albumin-bound zinc concentrations in plasma (Fig. 1), but not among $\mathrm{ACTH}$, total zinc, and $\alpha_{2}$-MG-bound zinc. The increase of ACTH release, though less in its extent, resembled that reported by UsATEGUi et al. (1977) in plasma of cold-exposed rats. UsATEGui et al. (1977) found that acute cold exposure leads to an increase in plasma ACTH, but the enhanced release of ACTH is of short duration, irrespective of the length of cold exposure. The present study suggests that ACTH response in human plasma after acute exposure to cold is prolonged compared to that of ACTH in the plasma of rats. It was noted that the elevated ACTH did not cause the increase in plasma cortisol in the present study. 


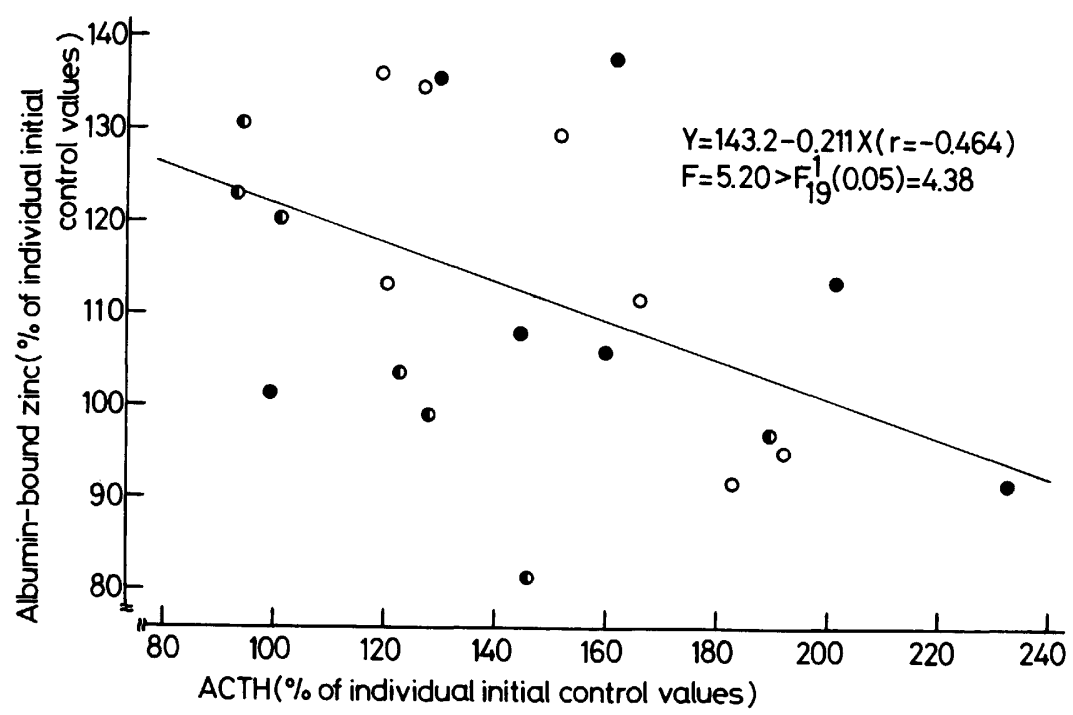

Fig. 1. Correlation between ACTH and albumin-bound zinc concentrations in plasma under acute exposure to cold. after 15-min cold exposure, $\bigcirc$ after 60 -min cold exposure, $15 \mathrm{~min}$ after cold exposure.

When hemoconcentration was taken into account, there appeared to be rather an efflux of cortisol from the plasma. Under acute exposure to cold, cortisol in human plasma has been reported to be slightly increased (SuzuKi et al., 1967; WiLson et al., 1970), unchanged (WILKERSON et al., 1974), or slightly decreased (GolsTEINGolaIRE et al., 1970). Such different results may be due to different experimental conditions such as clothing, blood-collecting time, and duration and temperature of cold exposure. The report by TATAI (1964) of markedly increased urinary excretion of 17-hydroxycorticosteroids in man following cold exposure, may point to an elevated clearance rate of cortisol by the cold in man. Glucocorticosteroid hormones seem to be capable of producing depressed plasma zinc values under acute stresses (BEISEL et al., 1976). However, FALCHUK (1977) has speculated that the decrease in serum zinc content that follows ACTH infusion does not appear to be mediated through release of adrenal hormones since the response is also observed in adrenalectomized patients. In the present study there was no relationship between cortisol and zinc concentrations. It was suggested, thus, that cortisol plays no important role in plasma zinc metabolism during acute exposure to cold.

The zinc present in human serum is principally composed of two fractions: one fraction is firmly bound to $\alpha_{2}-\mathrm{MG}$ and the other is more loosely associated with albumin (GIROUX, 1975). It has been reported that although albumin-bound zinc in plasma fluctuates under various physiological or pathological conditions, $\alpha_{2}-\mathrm{MG}$ bound zinc is relatively constant (BOGDEN, 1980). The present study has shown that there is a significant inverse relationship between the changes in ACTH and 
albumin-bound zinc concentrations during cold exposure, in approximate agreement with the study of FALCHUCK (1977) in healthy and diseased subjects. Namely, acute cold exposure produces elevated plasma ACTH levels in man, with resultant zinc redistribution within the body. However, the question whether such changes in plasma zinc (especially albumin-bound zinc) during cold exposure are attributed to a direct effect of ACTH cannot be answered at present. It is summarized by BEISEL et al. (1976) that initial zinc depression in plasma during acute stresses is explained by its abrupt redistribution within the body and that movement of zinc from plasma especially to liver, rather than loss of zinc from the body, causes the initial response. Он et al. (1978) have also demonstrated that the increased synthesis of metallothionein (MT, a zinc-binding protein) in the liver of rats is accompanied by a reduction of plasma zinc during 24-h cold exposure. Zinc ions stabilize lysosomal and microsomal membranes of rat liver, both in vivo and in vitro (CHVAPIL et al., 1972). In addition, it is known that in rats the redistribution of zinc within the body is accompanied by the release of leukocytic endogenous mediators (LEM) and endogenous pyrogen (EP) (BEISEL et al., 1976). Effects of acute cold exposure on MT, LEM, and EP in humans, however, are still not known. Thus, although it has been demonstrated that cold-exposed zinc-deficient rats show an impairment of homeothermia which increases with the duration of dietary manipulation of zinc (ToPPING et al., 1981), definite physiological significance of zinc redistribution in the human body during cold exposure awaits further study.

\section{REFERENCES}

Beisel, W. R., Pekarek, R. S., and Wanneamacher, R. W., Jr. (1976) Homeostatic mechanisms affecting plasma zinc levels in acute stresses. In: Trace Elements in Human Health and Disease, ed. by Prasad, A. S., Academic Press, New York, Vol. 1, pp. $87-106$.

Bogden, J. D. (1980) Blood zinc in health and disease. In: Zinc in the Environment. Part II: Health Effects, ed. by Nriagu, J. O., John Wiley \& Sons, New York, pp. 137-169.

ChVAPIL, M., Ryan, J. N., and Zukoski, C. F. (1972) Effect of zinc on lipid peroxidation in liver microsomes and mitochondria. Proc. Soc. Exp. Biol. Med., 141: 150-153.

Doi, K., Ohno, T., Kurahashi, M., and Kuroshima, A. (1979) Thermoregulatory nonshivering thermogenesis in men, with special reference to lipid metabolism. Jpn. J. Physiol., 29: 359-372.

FALCHUK, K. H. (1977) Effect of acute disease and ACTH on serum zinc proteins. $N$. Engl. J. Med., 296: 1129-1134.

Giroux, E. L. (1975) Determination of zinc distribution between albumin and $\alpha_{2}$ macroglobulin in human serum. Biochem. Med., 12: 258-266.

Golstein-Golaire, J., Vanhaelst, L., Bruno, O. D., LeclercQ, R., and Copinschi, G. (1970) Acute effects of cold on blood levels of growth hormone, cortisol, and thyrotropin in man. J. Appl. Physiol., 29: 622-626.

JESSEN, K. (1980) An assessment of human regulatory nonshivering thermogenesis. Acta Anaesth. Scand., 24: 138-143.

Lowry, O. H., Rosebrough, N. J., Farr, A. L., and Randall, R. J. (1951) Protein 
measurement with the Folin phenol reagent. J. Biol. Chem., 193: 265-275.

Lukaski, H. C., Bolonchuk, W. W., Klevay, L. M., Milne, D. B., and Sandstead, H. H. (1984) Changes in plasma zinc content after exercise in men fed a low-zinc diet. Am. J. Physiol., 247: E88-E93.

Oh, S. H., Deagen, J. T., Whanger, P. D., and Weswig, P. H. (1978) Biological function of metallothionein. V. Its induction in rats by various stresses. Am. J. Physiol., 234: E282-E285.

Ohno, H., Yahata, T., Yamashita, K., Doi, R., Taniguchi, N., and Kuroshima, A. (1986) Zinc metabolism in human blood during acute exposure to cold. Res. Commun. Chem. Pathol. Pharmacol., 52: 251-264.

Ohno, H., Yamashita, K., Doi, R., Yamamura, K., Kondo, T., and Taniguchi, N. (1985) Exercise-induced changes in blood zinc and related proteins in humans. $J$. Appl. Physiol., 58: 1453-1458.

SNedecor, G. W. and Cochran, W. G. (1980) Statistical Methods, 7th ed., The Iowa State University Press, Ames, pp. 215-237.

Suzuki, M., Tonoue, T., Matsuzaki, L., and Yamamoto, K. (1967) Initial response of human thyroid, adrenal cortex, and adrenal medulla to acute cold exposure. Can. J. Physiol. Pharmacol., 45: 423-432.

TataI, K. (1964) Comparative studies of three major stressors in bioclimatology. Bull. Inst. Public Health (Tokyo), 13: 205-217.

Topping, D. L., Clark, D. G., and Dreosti, I. E. (1981) Impaired thermoregulation in cold-exposed zinc-deficient rats: Effect of nicotine. Nutr. Rep. Int., 24: 643-648.

Usategui, R., Gillioz, P., and Oliver, C. (1977) Effect of cold exposure on $\alpha$-MSH and ACTH release in the rat. Horm. Metab. Res., 9: 519.

Van Beaumont, W., Strand, J. C., Petrofsky, J. S., Hipskind, S. G., and Greenleaf, J. E. (1973) Changes in total plasma content of electrolytes and proteins with maximal exercise. J. Appl. Physiol., 34: 102-106.

Wilkerson, J. E., Raven, P. B., Bolduan, N. W., and Horvath, S. M. (1974) Adaptations in man's adrenal function in response to acute cold stress. J. Appl. Physiol., 36: $183-189$.

Wilson, O., Hedner, P., Laurell, S., Nosslin, B., Rerup, C., and Rosengren, E. (1970) Thyroid and adrenal response to acute cold exposure in man. J. Appl. Physiol., 28: 543-548. 